University of Wollongong

Research Online

Faculty of Engineering and Information

Faculty of Engineering and Information

Sciences - Papers: Part A

Sciences

$1-1-2015$

Radial consolidation response upon the application and removal of vacuum and fill loading

Kourosh Kianfar

University of Wollongong, kourosh@uow.edu.au

Buddhima Indraratna

University of Wollongong, indra@uow.edu.au

Cholachat Rujikiatkamjorn

University of Wollongong, cholacha@uow.edu.au

Serge Leroueil

Laval University

Follow this and additional works at: https://ro.uow.edu.au/eispapers

Part of the Engineering Commons, and the Science and Technology Studies Commons

Research Online is the open access institutional repository for the University of Wollongong. For further information contact the UOW Library: research-pubs@uow.edu.au 


\title{
Radial consolidation response upon the application and removal of vacuum and fill loading
}

\author{
Abstract \\ This Note presents a laboratory study using a Rowe cell to compare the consolidation responses upon \\ vacuum pressure and fill load application and removal. The influences of the duration of application and \\ removal of fill load and vacuum pressures on radial consolidation were investigated using excess pore- \\ water pressure, axial strain, and overconsolidation ratio. It is shown that the appropriate removal time for \\ vacuum pressure can be determined based on excess pore pressure responses.

\section{Disciplines} \\ Engineering | Science and Technology Studies

\section{Publication Details} \\ Kianfar, K., Indraratna, B., Rujikiatkamjorn, C. \& Leroueil, S. (2015). Radial consolidation response upon the \\ application and removal of vacuum and fill loading. Canadian Geotechnical Journal, 52 (12), 2156-2162.
}




\title{
RADIAL CONSOLIDATION RESPONSE UPON THE APPLICATION AND \\ REMOVAL OF VACUUM AND FILL LOADING
}

\author{
Kourosh Kianfar
}

BSc, MSc, PhD, MIEAust

Senior Geotechnical Engineer, Coffey Geotechnics, Wollongong, NSW Australia Honorary Research Fellow, Centre for Geomechanics and Railway Engineering; University of Wollongong, Wollongong City, NSW 2522, Australia

\section{Buddhima Indraratna}

BSc (Hons., Lond.), MSc (Lond.), DIC, PhD (Alberta), FTSE, FIEAust., FASCE, FGS

Professor of Civil Engineering, Faculty of Engineering,

Director, Centre for Geomechanics and Railway Engineering; University of Wollongong, Wollongong City, NSW 2522, Australia

\section{Cholachat Rujikiatkamjorn}

BEng (Hons), MEng (AIT), PhD

Associate Professor, Centre for Geomechanics and Railway Engineering. School of Civil Engineering, Faculty of Engineering, University of Wollongong, Wollongong City, NSW 2522, Australia

\section{Serge Leroueil}

Professor, Department of Civil Engineering, Laval University, Quebec, Canada

Words: 3713

Figures: 8

Tables: 1

Submitted to: Canadian Geotechnical Journal 


\title{
RADIAL CONSOLIDATION RESPONSE UPON THE APPLICATION AND REMOVAL OF VACUUM AND FILL LOADING
}

\section{Kourosh Kianfar, Buddhima Indraratna, Cholachat Rujikiatkamjorn and Serge Leroueil}

\begin{abstract}
This Technical Note presents a laboratory study using a Rowe cell to compare the consolidation responses upon vacuum pressure and fill load application and removal. The influences of the duration of application and removal of fill load and vacuum pressures on radial consolidation were investigated using excess pore water pressure, axial strain, and overconsolidation ratio. It is shown that the appropriate removal time for vacuum pressure can be determined based on excess pore pressure responses.
\end{abstract}




\section{INTRODUCTION}

Demand for suitable lands especially along the coastal areas where the majority of population would prefer to live and work necessitates the improvement of soft compressible soil prior to the construction of infrastructure. The main aims of the soft soil improvement are to increase its bearing capacity and reduce associated post construction settlement of the infrastructures. The combination of wick drains with the application of surcharge embankments and/or vacuum pressure has been one of the most popular and cheaper ground improvement techniques.

Kjellman (1952) originally proposed the idea of applying vacuum preloading to land reclamation using cardboard wick drains. Afterwards, this technique has been successfully used in different projects worldwide (Holtz, 1975; Chen and Bao, 1983; Bergado et al. 1998; Indraratna et al. 2005a, b). In land reclamation where higher surcharge load is needed and soil shear strength is relatively low, the combination of vacuum preloading with fill load can reduce the required height of the embankment and the consolidation time (Chu et al. 2000). As explained in several papers in the past by Indraratna et al. (2005b), Indraratna et al. (2013), Chai et al. (2005), Chu et al. (2000), the differences between vacuum and fill preloading are as follows:

(a) Vacuum pressure accelerates inward radial drainage hence isotropic compression, whereby outward (destabilising) lateral displacement is significantly supressed, thus increasing the embankment stability. Therefore, with vacuum pressure application, embankments can be raised more speedily.

(b) Although for a given applied 'equivalent' load (i.e. the summation of vacuum and fill loading), the ultimate consolidation settlement under $\mathrm{K}_{0}$ consolidation (i.e. no lateral displacement) is theoretically the same for the two schemes, the rate of excess pore pressure dissipation is often higher upon vacuum application (Indraratna et al. 2013).

In a practical sense, application of a vacuum and its effect are immediate. Fill surcharge is more gradual (ramp loading) and sometimes requires a 'rest period' to minimise the adverse effects of outward (destabilising) displacements. The above factors can be attributed to a 
higher rate of settlement and excess pore pressure dissipation especially at the initial stages of consolidation, which has often been observed through numerous case studies (Indraratna and Chu, 2005).

Indraratna et al (2013) investigated the effectiveness of traditional fill loading and the combination of fill load and vacuum pressure using degrees of consolidation based on pore pressure and strain. They showed that the back-calculated coefficients of radial consolidation obtained from the vacuum assisted consolidation are higher than those from fill loading application alone. For a given total applied load, the coefficients of radial consolidation increases with the vacuum-fill surcharge ratio. Kianfar et al (2013) established a non-linear flow relationship during radial consolidation. It was shown that the settlement and excess pore water pressure dissipation can be predicted quite well using the proposed relationship.

The main issue of the vacuum preloading is that if consolidation time becomes excessive, the operation costs of vacuum pumps can be uneconomical. Currently there is no criterion to determine the best time to remove the vacuum pressure. Often the contractors make the decision either on the basis of the approved budget in an arbitrary manner (e.g. contractually fixed time) or considering a pre-agreed value of settlement with the client/consultant (e.g. Port of Brisbane). However, in the above decisions, the most important advantage of applying vacuum pressure in conjunction with the surcharge fill, i.e. to maximise the gradient of excess pore pressure dissipation, is invariably overlooked. It has been demonstrated that the vacuum assisted consolidation can provide a significantly high rate of excess pore water dissipation especially during the early stages of consolidation while reducing the lateral displacement of the soil. As a result, the overlying fill (surcharge) can be placed much faster without affecting the embankment stability, and this helps in switching off the vacuum pressure earlier than waiting for primary consolidation to be fully completed. 
Although, numerous studies have been conducted to show the effectiveness of the application of vacuum pressure in conjunction with vertical drains, the effects of early removal of either vacuum or fill loading on axial strains and excess pore pressure are not yet addressed in detail, which is the main objective of this Note. The examination of long term settlement including secondary compression is not within the scope of this Technical Note.

\section{EXPERIMENTAL PROGRAMME}

Effects of the application and removal of fill and vacuum pressures on the radial consolidation of soft soils were studied using a modified 150mm diameter Rowe cell. Figure 1 schematically shows the cell equipped with instrumentation. Rigid impermeable discs were used at the base and top of the sample to allow only the radial consolidation. The measurement of pore water pressure at 4 locations was obtained using pore pressure transducers. The central hole at the top plate was used for drainage and application of vacuum pressure. Surface settlement was measured at the centre of the top of the cell. The inner wall of the Rowe Cell has been specially laminated by vinyl to minimise friction. This technique was proposed by Indraratna et al. (2013) for use when the height to diameter ratio becomes large. The initial response of the pore pressure reading being equal to the applied fill loading also confirms the satisfactory functioning of the cell.

Kaolin slurry was prepared with a moisture content of at least 1.5 times its liquid limit (water content $=88 \%$ ) and its properties have been reported by Kianfar et al. (2013). The slurry was carefully poured into the cell and later subjected to a preconsolidation pressure of $30 \mathrm{kPa}$ to simulate a typical in-situ stress. To ensure that the sample was saturated, Skempton's B parameter of at least 0.99 was obtained. To measure Skempton's B parameter, the drainage valve was closed and an additional vertical load was applied to measure the excess pore 
pressure response. For example, in Test 1, after the pre-consolidation (30 kPa) stage, an additional $50 \mathrm{kPa}$ was imposed with the drainage valve closed. The resulting immediate excess pore pressure response was $49.5 \mathrm{kPa}$, verifying near-saturation.

Following completion of preconsolidation (under $30 \mathrm{kPa}$ ), the preconsolidation pressure was removed and a central vertical sand drain (14.5 mm in diameter) was installed within a rebored hole to minimise the smear effect. The $30 \mathrm{kPa}$ preconsolidation pressure was then reapplied. Fill pressure was applied on top of the sample and vacuum pressure was applied through the central drain. This method of the vacuum pressure application simulates the membraneless system where a vacuum pump connects directly to the vertical drains (Indraratna et al. 2013). After the preconsolidation stage, additional fill pressure was applied under undrained conditions for 10-15 minutes to ensure the excess pore water pressure was uniform within the sample (i.e. equal to the applied fill surcharge). When an external load is applied to the soil samples under undrained conditions, the increase in the excess pore water pressure is almost instant. The fill loading was applied under undrained condition so that the initial excess pore pressure was constant in the Rowe cell sample. For the vacuum assisted tests, a vacuum was applied simultaneously when the drainage valve was opened. The vacuum pressure was applied directly through the vertical drain, i.e. via the drainage rod (Figure 1). The drain was connected to a stand-pipe piezometer filled with water to simulate the effect of the water table in the field. This would also allow a reverse movement of water from the drain to the soil and prevent air from entering into the soil specimen during the unloading stage.

Details of six different tests are summarized in Table 1 . The testing program was planned based on the following scenario, in which the clay specimen was subjected to an initial preconsolidation pressure of $30 \mathrm{kPa}$ in order to achieve a desired effective stress of $80 \mathrm{kPa}$ upon 
complete consolidation (i.e. in-situ pressure plus additional gain of effective stress by preloading), while the applied total pressure was $100 \mathrm{kPa}$. This typical loading scheme was considered during the selection of consolidation techniques for a land reclamation project at the Port of Brisbane, Australia. Further information on the preconsolidation pressure profile, and computed magnitude of the final primary settlement of the ground surface is given elsewhere by Indraratna et al (2011). Table 1 indicates the applied (equivalent) stress not the actual total stress in the soil. As explained by Indraratna et al. (2013), the application of vacuum pressure $(50 \mathrm{kPa})$ with fill pressure $(50 \mathrm{kPa})$ results in an increase in the total stress of $50 \mathrm{kPa}$. However, the gain in effective stress is $100 \mathrm{kPa}$ due to the direct change in excess pore pressure caused by both suction and fill pressure. Therefore the total applied stress between the combination of vacuum+fill loading $(50+50=100 \mathrm{kPa})$ and the fill loading $(100 \mathrm{kPa})$ is the same (equivalent). To accelerate the consolidation process and minimise possible shear failure of the shallow dredged mud, rather than applying $50 \mathrm{kPa}$ fill load alone, an additional vacuum pressure or fill pressure of $50 \mathrm{kPa}$ was added. Therefore, the total applied load of $100 \mathrm{kPa}$ (summation of vacuum plus fill pressures) was the same for all tests. Loading application could be divided into 3 distinct stages:

(a) Stage A: For Tests 1-3, a total of $100 \mathrm{kPa}$ fill pressure alone was applied at the start of the tests. For Tests 4-6, a fill pressure of $50 \mathrm{kPa}$ was initially applied simultaneously with a vacuum pressure of $50 \mathrm{kPa}$.

(b) Stage B: Half of the fill pressure (50 kPa) was then removed after 8, 10, and 12 hours for Tests 1-3, respectively. For Tests $4-6$, the vacuum pressure was entirely removed after 8,10 , and 12 hours, respectively.

(c) Stage C: The remaining fill (50 kPa) was removed after 72 hours.

Mohamedelhassan and Shang (2002) and Chai et al (2005) conducted vacuum consolidation tests under vertical drainage using a modified oedometer, where the vacuum pressure was 
applied at the soil surface. Chai et al. (2005) proposed that soil deformation under vacuum application depends on the stress ratio which can be modified for the combination of fill and vacuum loading as:

$$
k=\frac{\Delta \sigma_{v a c}}{\left(\Delta \sigma_{v a c}+\Delta \sigma_{f i l l}+\sigma_{v 0}^{\prime}\right)}
$$

where, $\Delta \sigma_{v a c}$ is the vacuum pressure, $\Delta \sigma_{f i l l}$ is the fill pressure and $\sigma_{v 0}^{\prime}$ is the initial vertical effective stress.

At rest, the coefficient of horizontal earth pressure for the normally consolidated clays is calculated from $k_{0}=1-\sin \varphi^{\prime}$ where $\varphi^{\prime}$ is the effective friction angle.

For tests subjected to vacuum preloading, $\Delta \sigma_{v a c}=\Delta \sigma_{\text {fill }}=50 \mathrm{kPa}$, and $\sigma_{v 0}^{\prime}=30 \mathrm{kPa}$, the Stress Ratio $(k)$ is 0.385 , which is less than $k_{0}=0.546$ where the friction angle of the clay is $27^{0}$. According to Chai et al (2005), when the stress ratio is less than $k_{0}$, there is no inward lateral displacement and the ultimate settlements would be almost the same as that induced by conventional fill loading. Preliminary test results show that complete consolidation curves for either fill or vacuum load applied up to 50 days converge to the same ultimate settlement. 


\section{EXCESS PORE WATER PRESSURE RESPONSES}

To normalise the radial distance from the centre of the cell, a Radius Ratio (RR) was defined as:

$$
R R=\left(r-r_{w}\right) /\left(R-r_{w}\right)
$$

where, $r$ is the radius from the centre, $r_{w}$ is the radius of the vertical drain, and $R$ is the radius of the cell.

The locations for pore water pressure measurement were at $\mathrm{RR}=0.0,0.19,0.48$, and 0.77 . The distributions of excess pore water pressure at different radii for Tests 1-3 are presented in Figure 2. It shows that there were three distinct excess pore pressure responses during the application and removal of the applied surface surcharge (i.e. simulating the fill placement and removal in the field):

(a) when the surface 'fill' load was first applied,

(b) when the first half of the 'fill' surcharge was removed, and

(c) when the second half of the 'fill' surcharge was removed.

[Note: the term 'fill' loading represents the axial stress which simulates fill placement in the field]

Upon the application of the surface 'fill' load, the excess pore water pressure first increased more than the applied load at $\mathrm{RR}=0.77$ and decreased at the locations closer to the drain. This phenomenon can be attributed to the rigid boundary contributing to the Mandrel-Cryer effect. After approximately half an hour, all excess pore water pressure curves show a similar trend as the Mandrel-Cryer effect diminishes. The pore pressure closest to the drain decreased faster than that away from the drain. Upon the removal of the first half of the surface load, the drop in excess pore water pressure was immediate and varied with the radial distance 
from the drain. In all cases, the excess pore pressures after the $1^{\text {st }}$ stage of removal did not become negative, and were the highest in Test 1 where the consolidation time was shorter.

When the excess pore water pressures dissipated completely (after 72 hours), the remaining surface load (50 kPa) was completely removed (Fig. 2). As the excess pore pressures for all tests approached zero, it is interesting to note that the pore water pressures after the load removal became negative (suction) for at least 15 hours before they returned to zero. The negative pore pressures could be attributed to the tendency of the soil to expand. Considering the expected rapid drainage at the drain-soil interface, negative excess pore pressures quickly increase to zero when the measuring point is much closer to the drain.

Time-dependent excess pore water responses for the vacuum assisted tests (Tests 4-6) are presented in Fig. 3. As expected, for a given total applied pressure $(100 \mathrm{kPa})$, the initial excess pore water pressures obtained from Tests 4-6 were less than those obtained from Tests 1-3. Unlike the surface 'fill' pressure, the removal of vacuum pressure increased the excess pore water pressure in the soil specimens (see Fig 3). In tests 4 and 5, depending on the removal time of the vacuum pressure, prior to the vacuum removal, the excess pore water pressures were negative at $\mathrm{RR}=0.19$ and positive at other measurement points; while they were negative at all measuring locations in Test 6.

Figure 4 presents the average excess pore pressure responses computed based on simple numerical average where the average excess pore pressure was calculated from the excess pore pressures measured at 4 locations without the influence of the hydrostatic pressure. The sample height was $80 \mathrm{~mm}$ and the excess pore pressure measurement was carried out at the base. Therefore during calculations, the hydrostatic pore pressure was subtracted from the total pore pressure reading. It is noted that the left and right vertical axes are for Tests 1-3 and Tests 4-6, respectively. As expected, the initial excess pore pressures obtained from the tests with fill loading alone were higher than those with the combination of vacuum and fill 
pressure. Excess pore pressure dissipation rates under vacuum pressure are higher compared to those under fill loading alone which is similar to observation made by Indraratna et al. (2013). Due to the scale of the graphs, the differences are less visible for Cases B and C. Ideally, all curves under the same loading condition should coincide, however, these minor differences are inevitable during testing and unfortunately the responses are not identical.

For Stage B, upon the removal of first half of the surcharge in Tests 1-3, the drop in excess pore water pressure was immediate and the excess pore pressures continued to dissipate to zero afterwards. Prolonged removal time of the surcharge creates lesser residual excess pore pressure in Stage B. As explained by Aldrich (1965), for a given total stress, the specimens which experience a longer consolidation time have a higher effective stress. Unlike the surcharge pressure, the removal of vacuum pressure in Tests 4-6 caused a sudden increase in the excess pore water pressure. Depending on the removal time of the vacuum pressure, the average excess pore pressures were positive, and further dissipation was observed in Stage B (Tests 4 and 5). This is because, the average effective stress in the specimens was less than the total stress. In Test 6, the average excess pore water pressure was negative at the end of Stage A, and later increased to zero (hydrostatic) after vacuum removal, and then remained constant (at zero) thereafter. This is because the current average effective stress of the soil specimen in Test 6 , immediately after vacuum pressure removal, was at least equal to or greater than the total external surcharge load (50 kPa).

If the desired effective stress of soil after consolidation is $80 \mathrm{kPa}$ (in-situ pressure + preloading pressure), it is implied that the optimum removal time can be at 12 hours (Test 6) where the average excess pore pressures were negative. For a given removal time, the initial excess pore pressure in Stage B with vacuum application is always less than those with fill 
load. For Stage C, before the removal of the remaining fill load, excess pore pressures for all Tests were zero. It is interesting to note that the pore water pressures after the load removal became negative (suction) for at least 15 hours before they returned to zero. The negative pore pressures result from the tendency of the soil to swell upon unloading and this induced the inverse movement of water from the drain to the soil. The delay in the removal of the fill load has less effect on excess pore water pressure responses, while the extended period of vacuum removal imparts a greater influence on the change in excess pore water pressure.

\section{DETERMINATION OF VACUUM REMOVAL TIME}

The pore water pressure response indeed could be used as a prime indicator to remove vacuum application. The advantage of the vacuum pressure diminishes with time as the primary consolidation progresses, i.e. gradient of the time-settlement curve at a given time. The normalised pore pressure dissipation rate and axial stain rate from Test 6 can be determined from the ratio of pore pressure dissipation rate or axial stain rate with its maximum rate at the initial consolidation stage (Figure 5). It can be seen that the vacuum pressure accelerates consolidation settlement significantly at the start, but subsequently a flatter pore water pressure curve after 8-10 hours is observed earlier than the axial strain response. When the gradient of the curve becomes less, the benefit of maintaining the vacuum pressure are only marginal, and therefore, the amount of undissipated pore water pressure and its current rate of dissipation (du/dt) give a clear indication to make the decision whether to continue or switch-off the vacuum pumps. For Port of Brisbane reclamation, Indraratna et al. (2011) considered the degree of consolidation based on pore pressure dissipation rate as a key indicator to either maintain or switch off the vacuum pressure. Piezometers are crucial component of the common instrumentation array to monitor the behaviour of the embankment, and relate the rate of settlement at a given time to the undissipated pore water pressure at critical locations beneath the embankment. 
For example, if the required increase in effective stress due to surcharge is $50 \mathrm{kPa}$ and the maximum fill surcharge pressure cannot exceed $50 \mathrm{kPa}$ due to relatively low undrained shear strength of the soft clay, then the application of vacuum in tandem with surcharge fill will be required. With the application of an additional $50 \mathrm{kPa}$ vacuum pressure (i.e. an equivalent total load of $100 \mathrm{kPa}$ ), the vacuum pump can be switched off when the remaining excess pore water pressure approaches a small value, which will take a long time to dissipate totally. For example, at the Port of Brisbane reclamation works, it was found that the excess pore pressure gradient was more sensitive than the time-settlement plot, hence the pore pressure dissipation rate was more convenient to use than the settlement for determining the time for vacuum removal.

\section{COST ANALYSIS TO SHOW THE NEED FOR EARLY REMOVAL}

For the Port of Brisbane project where vacuum application was employed, the cost savings for early switching off vacuum pump was approximately A $\$ 150,000$ per month for each improved area less than $15000 \mathrm{~m} 2$ (i.e. A $\$ 10$ per sq.m) in 2008. It is expected that the operating cost of the system will exceed $A \$ 200,000$ per month for a similar project and soil conditions under current Australian rates. If the vacuum system could be switched off even a few weeks earlier, then the cost saving would be as much as half a million dollars over 15000 sq.m. In fact, this was demonstrated through a field trial at the Port of Brisbane reclamation site.

The capital cost of vacuum system installation is relatively high (and this is one of the impediments in using VP for small projects), but so are the running costs as explained above. In very large projects where soft clay deposits are thick, the total running costs significantly exceed the initial capital costs if the vacuum pressure has to be applied over a lengthy period of time. Early vacuum switch off is crucial, so that the remaining excess pore pressure would dissipate under the surcharge fill height, which as mentioned earlier could be raised very 
quickly without affecting stability, because of the key advantage of vacuum pressure that actively controls the lateral soil displacement.

\section{CONSOLIDATION SETTLEMENT RESPONSES}

The axial strains for the tests conducted with conventional fill loading alone and those with a combination of fill loading and vacuum are presented in Fig. 6. When the first half of the external loads in Stage B (fill or vacuum pressure) were removed, the vacuum assisted tests (Tests 4-6) produce a higher axial strain rate for a given time than those tests conducted with fill load alone (Tests 1-3). After the removal of the applied load in the Stage C, swelling can be observed with the negative excess pore pressure shown in Fig. 4. No further settlement can be observed in Test 6 after the vacuum pressure removal at 12 hours. This also is in accordance with the observation of no excess pore pressure dissipation shown in Fig. 4.

\section{AVERAGE OVERCONSOLIDATION RATIO}

To distinguish clearly the difference between fill surcharge and vacuum pressure, the increase in the average effective stresses computed using average values of pore water pressure of all of the tests were calculated and plotted in Fig. 7. The average pore water pressure is determined based on a simple numerical average of values at 3 locations. This Figure compares the gain in effective stress before and after the removal of external loads with the time for removing the fill/vacuum load. It shows that the gain in average effective stress before removing the external loads (fill or vacuum load) is on the average about $23 \%$ greater than that for tests conducted using fill pressure alone. Figure 7 also shows that this difference after removing the external loads increased to an average of $39 \%$. This clearly shows the advantage of using vacuum pressure over conventional fill surcharge alone, especially when the embankment stability is crucial. These observations imply important practical implications between the two approaches. 
Preconsolidation pressure $\left(\mathrm{p}_{\mathrm{c}}^{\prime}\right)$ at the end of each test can be estimated by adding the initial effective stress $\left(\mathrm{p}_{0}^{\prime}=30 \mathrm{kPa}\right.$ ) to the total amount of pore pressure dissipation (which can be calculated from Fig. 4). Figure 8 shows the associated overconsolidation ratio (OCR) versus the removal time of the fill load/vacuum pressure.The performance between fill and vacuum preloading can be assessed using the overconsolidation ratio (OCR), as at the end of each test, the preconsolidation pressures were not the same due to the load application type and the removal time. It can be seen that the combination of vacuum and 'fill' surcharge provides a higher OCR than using 'fill' alone, which is consistent with the observed excess pore pressures and strains. The increase in OCR depends on the removal time for both cases. It is shown that OCR can be used as an indicator to compare the performance of both systems. OCR can be determined using a number of techniques such as the change in excess pore pressure and an oedometer test for the soil samples at the end of preloading (Marques et al. 2003).

\section{CONCLUSION}

In essence, the application of combined vacuum and fill surcharge preloading can effectively decrease the height of fill required to achieve the same degree of consolidation, while enabling much better control of lateral soil movement that may otherwise become excessive in the absence of vacuum pressure. This is supported by the experimental observations of the differences in effective stress associated with the two approaches (i.e. conventional fill surcharge alone vs combined vacuum and fill surcharge).

Six consolidation tests were carried out using a Rowe cell that can measure pore pressure at 4 different locations and axial settlement. Kaolin specimens prepared under preconsolidation pressure of $30 \mathrm{kPa}$ were used to perform radial consolidation under the combination of 
vacuum and fill pressure. Partial fill load or vacuum pressure was removed at different times. Following specific observations can be made:

(a) For a given total applied load, the initial excess pore pressures due to fill pressure alone were higher than those with the combination of vacuum and fill pressure. Excess pore pressure dissipation under vacuum pressure is faster compared to those under fill surcharge alone.

(b) Upon the partial removal of fill surcharge, the drop in excess pore water pressure was immediate and the excess pore pressures continued to dissipate to zero afterwards. In contrast, the removal of vacuum pressure created a sudden increase in the excess pore water pressure. However, if the excess pore pressure was negative before vacuum removal, the excess pore water pressures increased to zero (hydrostatic) and remained constant at zero with no further settlement thereafter. The time for removal of the vacuum pressure can be decided upon the pore pressure response.

(c) The application of vacuum and fill pressure yields a higher OCR than using fill load alone. The change in OCR depends on the removal time for both cases.

(d) The gain in average effective stress before removing the external loads (fill or vacuum) is on the average about $23 \%$ greater than that for tests conducted using fill surcharge alone. This clearly shows the advantage of using vacuum pressure over conventional fill surcharge alone, especially when the embankment stability is crucial. 


\section{ACKNOWLEDGEMENT}

The Authors acknowledge the financial support provided by Australian Research Council, and support from the Centre for Geomechanics and Railway Engineering, University of Wollongong, NSW, Australia. 


\section{REFERENCES}

Aldrich, H. P. (1965. Precompression for support of shallow foundations. J. Soil Mech. Found. Div., ASCE , 91 (2), 5-20.

Bergado, D. T., Chai, J. C., Miura, N., and Balasubramaniam, A. S. 1998. PVD improvement of soft Bangkok clay with combined vacuum and reduced sand embankment preloading. J. Geotech. Eng., 29 (1), 95-121.

Chai, J.-C, Carter, J. P. and Hayashi, S. 2005. Ground deformation induced by vacuum consolidation. J. of Geotechnical and Geoenvironmental Engineering, ASCE, 131(12), 1552-1561.

Chen, H., and Bao, X. C. 1983. Analysis of soil consolidation stress under the action of negative pressure. Proceedings of 8th European Conference on Soil Mechanics and Foundation Engineering, 2 591-596.

Chu, J., Yan, S. W., and Yang, H. 2000. Soil Improvement by the Vacuum Preloading Method for an Oil Storage Station. Géotechnique, 50 (6), 625-632.

Holtz, R. D. 1975. Preloading by vacuum: current prospects. Transportation Research Record, No. 548 26-79.

Indraratna, B. and Chu, J. 2005. Ground Improvement - Case Histories. Elsevier Scientific (UK). 38 Edited Chapters, 1115 pages

Indraratna, B., Rujikiatkamjorn, C., and Sathananthan, I. 2005a. Analytical and Numerical Solutions for a Single Vertical Drain Including the Effects of Vacuum Preloading. Canadian Geotechnical Journal, 42 (4), 994-1010.

Indraratna, B., Sathananthan, I., Rujikiatkamjorn, C., and Balasubramaniam, A. S. 2005b. Analytical and Numerical Modeling of Soft Soil Stabilized by Prefabricated Vertical Drains Incorporating Vacuum Preloading. International Journal of Geomechanics, 5 (2), 114-124. 
Indraratna, B., Rujikiatkamjorn, C., Ameratunga, J., and Boyle, P. 2011. Performance and Prediction of Vacuum Combined Surcharge Consolidation at Port of Brisbane. J. of Geotechnical \& Geoenvironmental Engineering, ASCE, 137 (11), 1009-1018.

Indraratna, B., Kianfar, K., and Rujikiatkamjorn, C. 2013. Laboratory Evaluation of coefficient of Radial Consolidation based on Pore-Water Pressure Dissipation and Settlement, ASTM Geotechnical Testing Journal, 36(1), 1-12.

Kianfar, K., Indraratna, B., and Rujikiatkamjorn, C. 2013. Radial Consolidation Model incorporating the Effects of Vacuum Preloading and Non-Darcian Flow, Géotechnique, 63(12), 1060-1073.

Kjellman, W. 1952. Consolidation of Clayey Soils by Atmospheric Pressure, Proceedings of a Conference on Soil Stabilization, Massachusetts Institute of Technology, Boston, 258-263.

Marques, M.E.S., Leroueil, S. and Almeida, M. S. S. 2003. Performance of instrumentation under vacuum consolidation and vacuum consolidation and heating, $12^{\text {th }}$ Panamerican Conference on Soil Mechanics and Geotechnical Engineering, (Rock Soil America 2003), Boston, 22-26 June 2003, 2, 2641-2648.

Mohamedelhassan, E. and Shang, J. Q. 2002. Vacuum and surcharge combined onedimensional consolidation of clay soils. Can. Geotech. J. 39, 1126-1138. 
Table 1: Information of the test conducted using a $150 \mathrm{~mm}$ Rowe Cell

\begin{tabular}{|c|c|c|c|c|c|c|c|c|}
\hline $\begin{array}{l}\text { Test } \\
\text { No. }\end{array}$ & $\begin{array}{c}\text { Sample } \\
\text { Diameter } \\
(\mathbf{m m})\end{array}$ & $\begin{array}{c}\text { Drain } \\
\text { Diameter } \\
(\mathbf{m m})\end{array}$ & $n$ & $\begin{array}{c}\text { Fill } \\
\text { Pressure } \\
\text { (FP, kPa) }\end{array}$ & $\begin{array}{l}\text { Vacuum } \\
\text { Pressure } \\
\text { (VP, kPa) }\end{array}$ & $\begin{array}{c}F P \\
+V P \\
(\mathbf{k P a})\end{array}$ & $=\frac{\begin{array}{c}V S R \\
F P+V P\end{array}}{F P}$ & $\begin{array}{c}\text { Time of } \\
\text { Fill or } \\
\text { Vacuum } \\
\text { Removal } \\
\text { (hr) }\end{array}$ \\
\hline 1 & \multirow{6}{*}{151} & \multirow{6}{*}{14.5} & \multirow{6}{*}{10.41} & 100 & 0 & \multirow{6}{*}{100} & 0 & 8 \\
\hline 2 & & & & 100 & 0 & & 0 & 10 \\
\hline 3 & & & & 100 & 0 & & 0 & 12 \\
\hline 4 & & & & 50 & 50 & & 0.5 & 8 \\
\hline 5 & & & & 50 & 50 & & 0.5 & 10 \\
\hline 6 & & & & 50 & 50 & & 0.5 & 12 \\
\hline
\end{tabular}




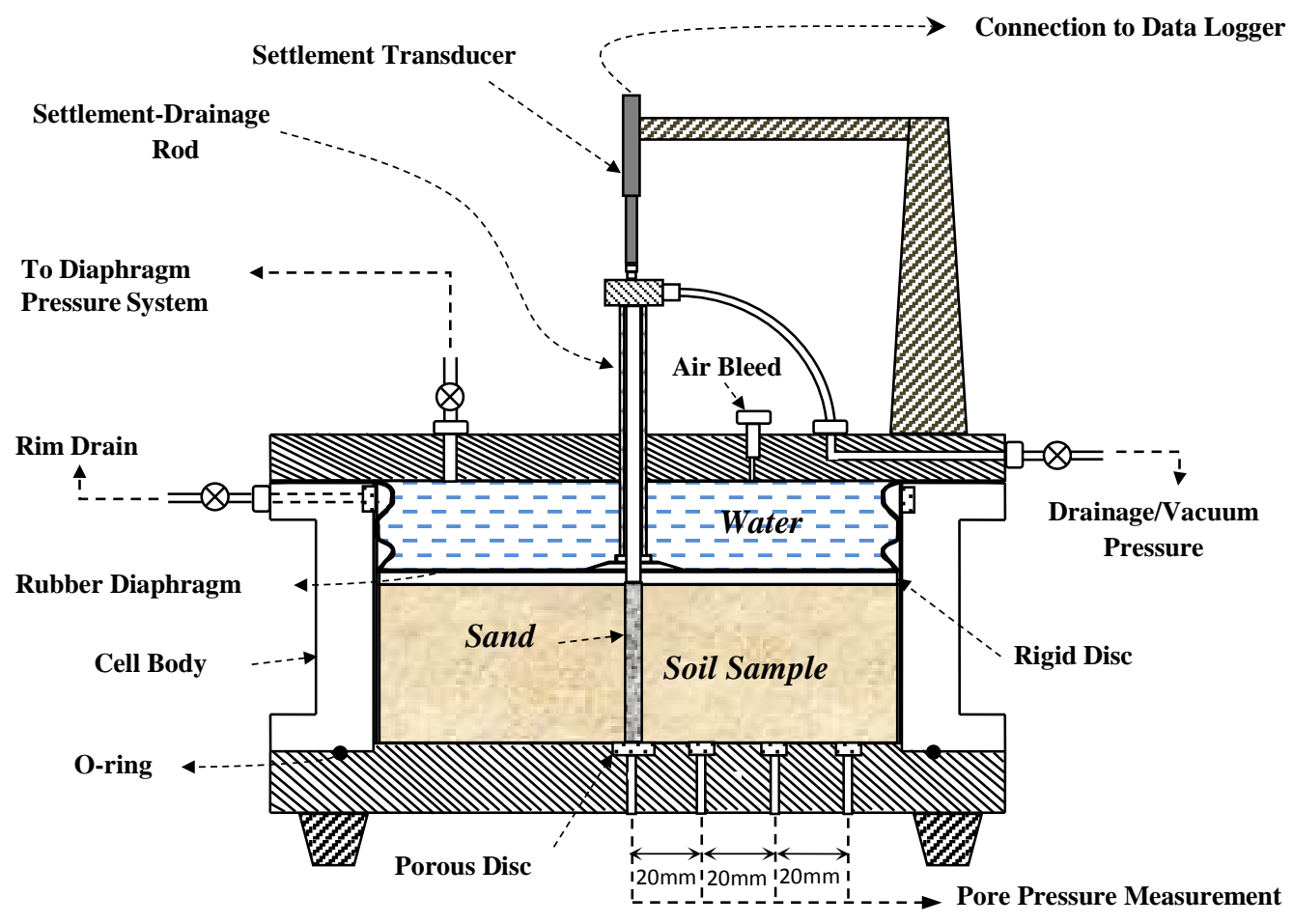

Figure 1: Modified $150 \mathrm{~mm}$ Rowe cell 


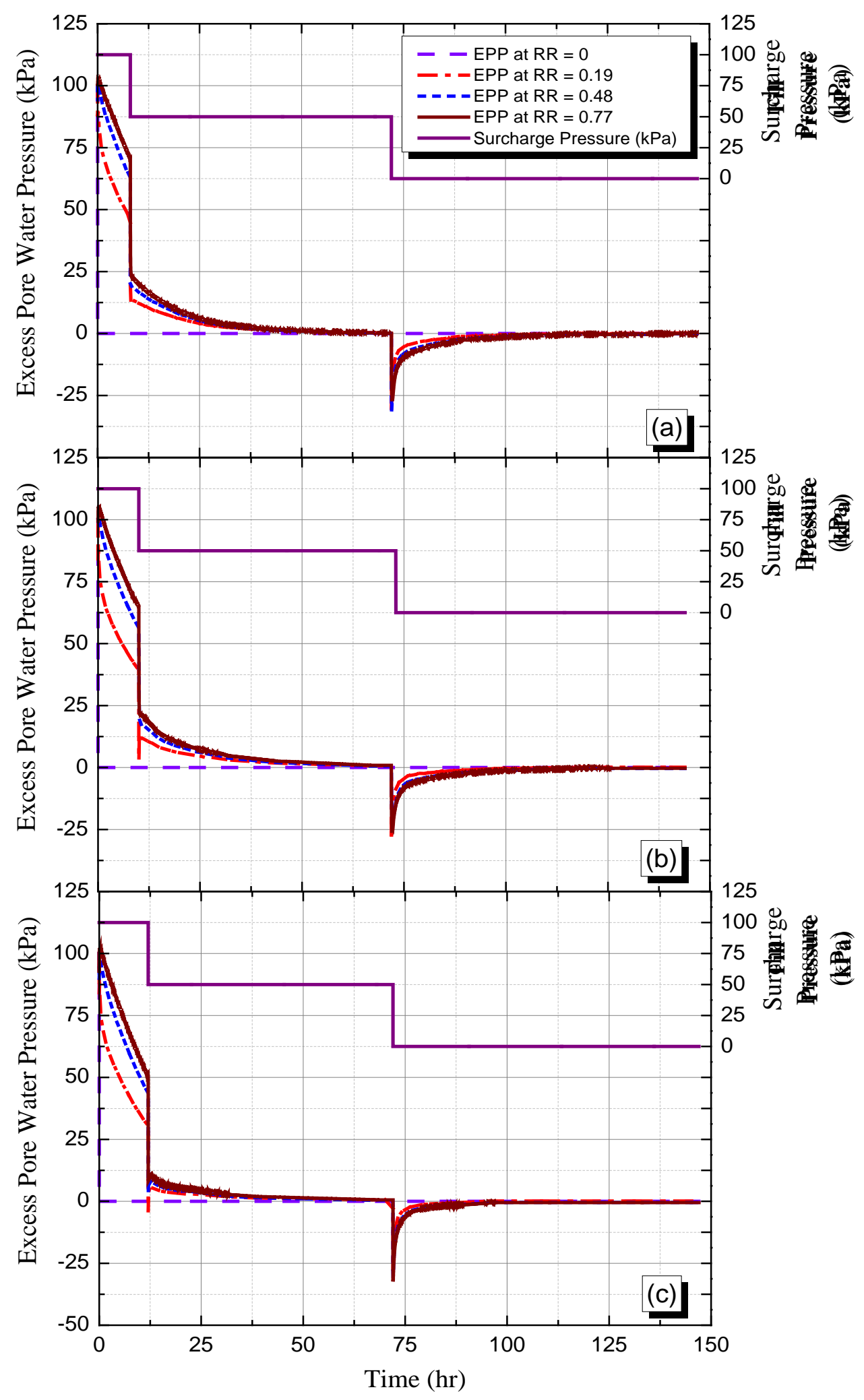

Figure 2: Excess pore water pressure distribution with time at different radii: (a) Test 1: removal of $50 \mathrm{kPa}$ fill load after 8.0 hours,(b) Test 2: removal of $50 \mathrm{kPa}$ fill load after 10.0 hours,(c) Test 3: removal of $50 \mathrm{kPa}$ fill load after 12.0 hours. 


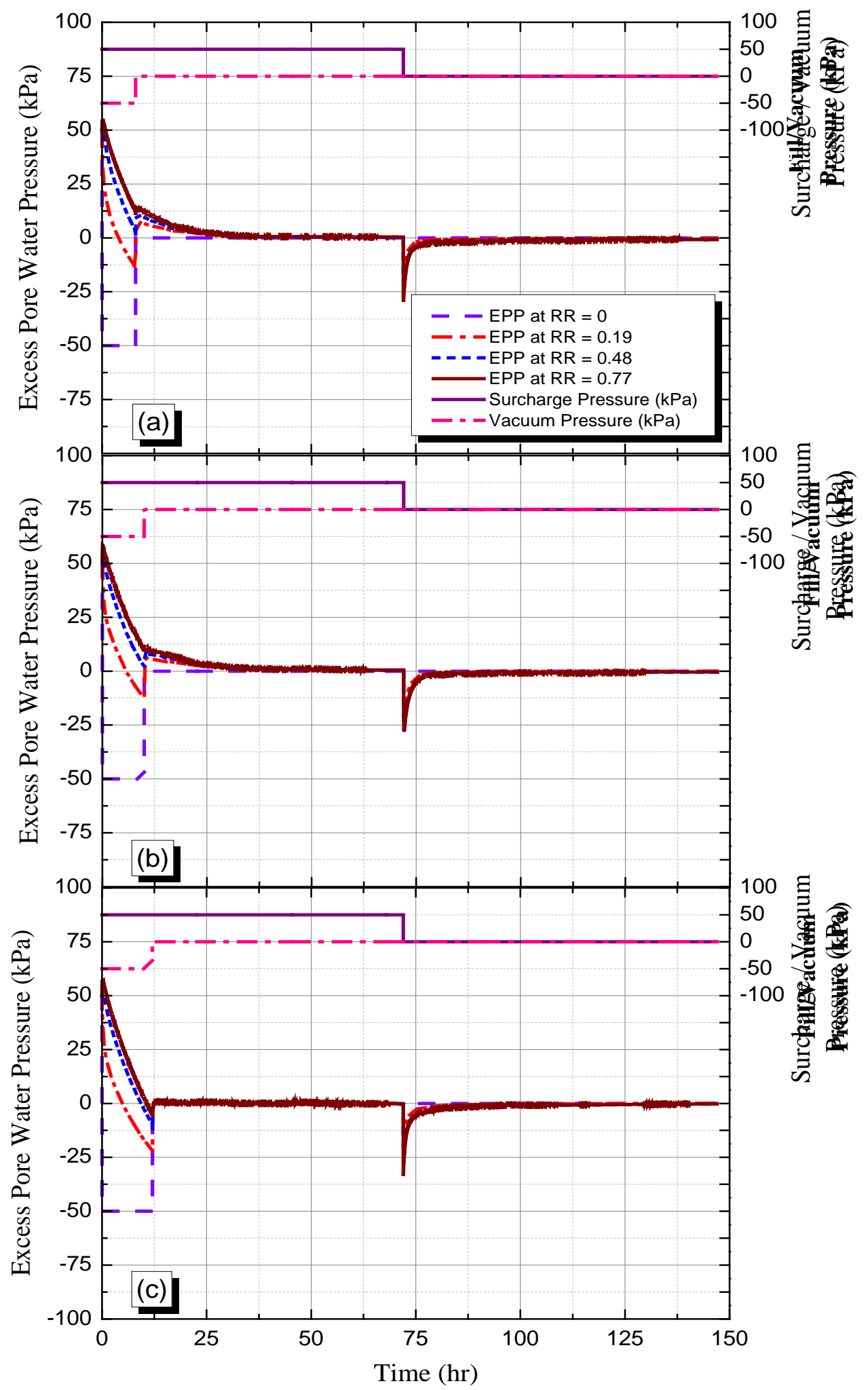

Figure 3: Excess pore water pressure distribution with time at different radii: (a) Test 4: removal of $50 \mathrm{kPa}$ vacuum after 8.0 hours,(b) Test 5: removal of $50 \mathrm{kPa}$ vacuum after 10.0 hours, (c) Test 6: removal of $50 \mathrm{kPa}$ vacuum after 12.0 hours. 


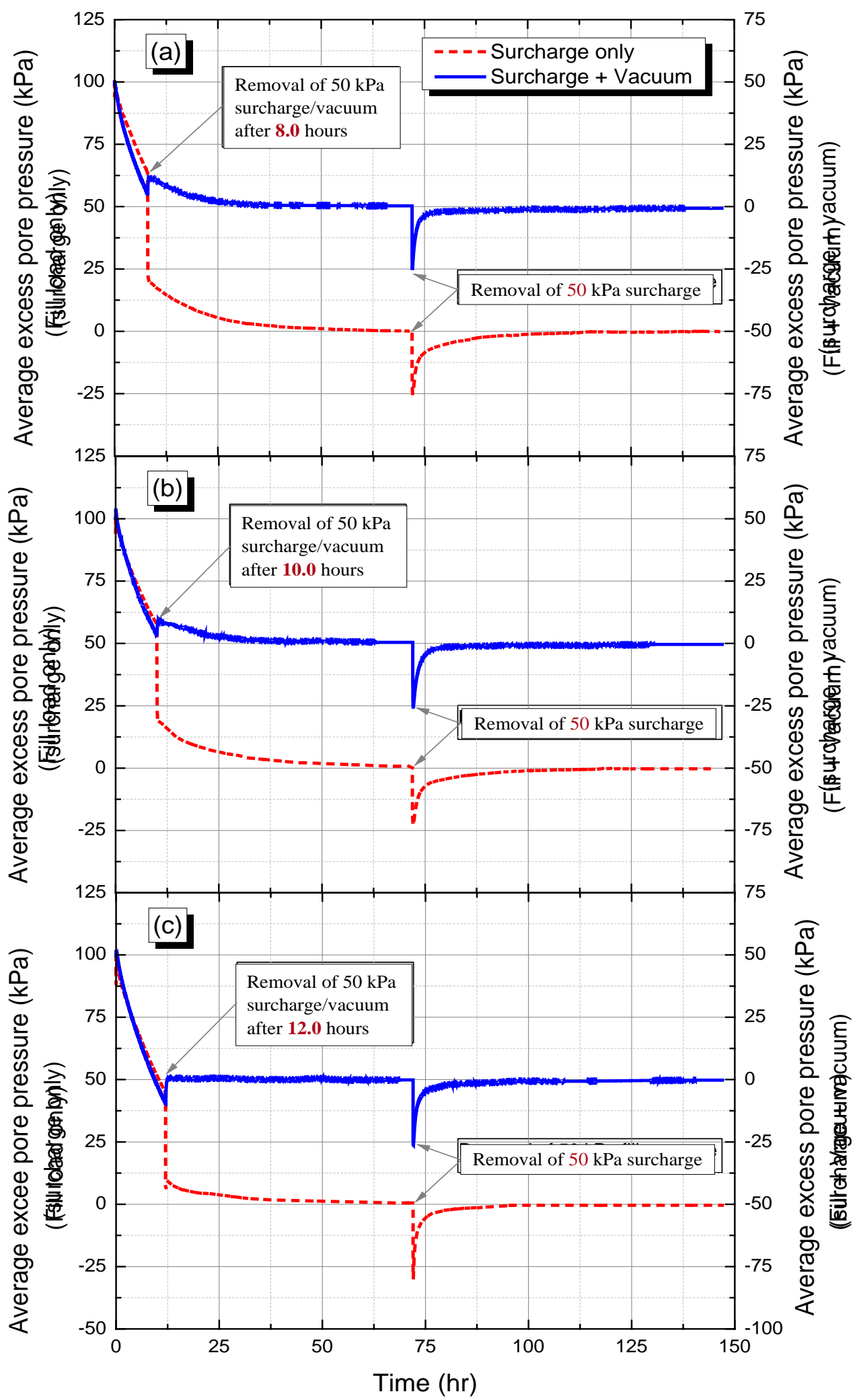

Figure 4: Average excess pore water pressures for: (a) fill/vacuum removal at 8.0 hours, (b) fill/vacuum removal at 10.0 hours,(c) fill/vacuum removal at 12.0 hours. 


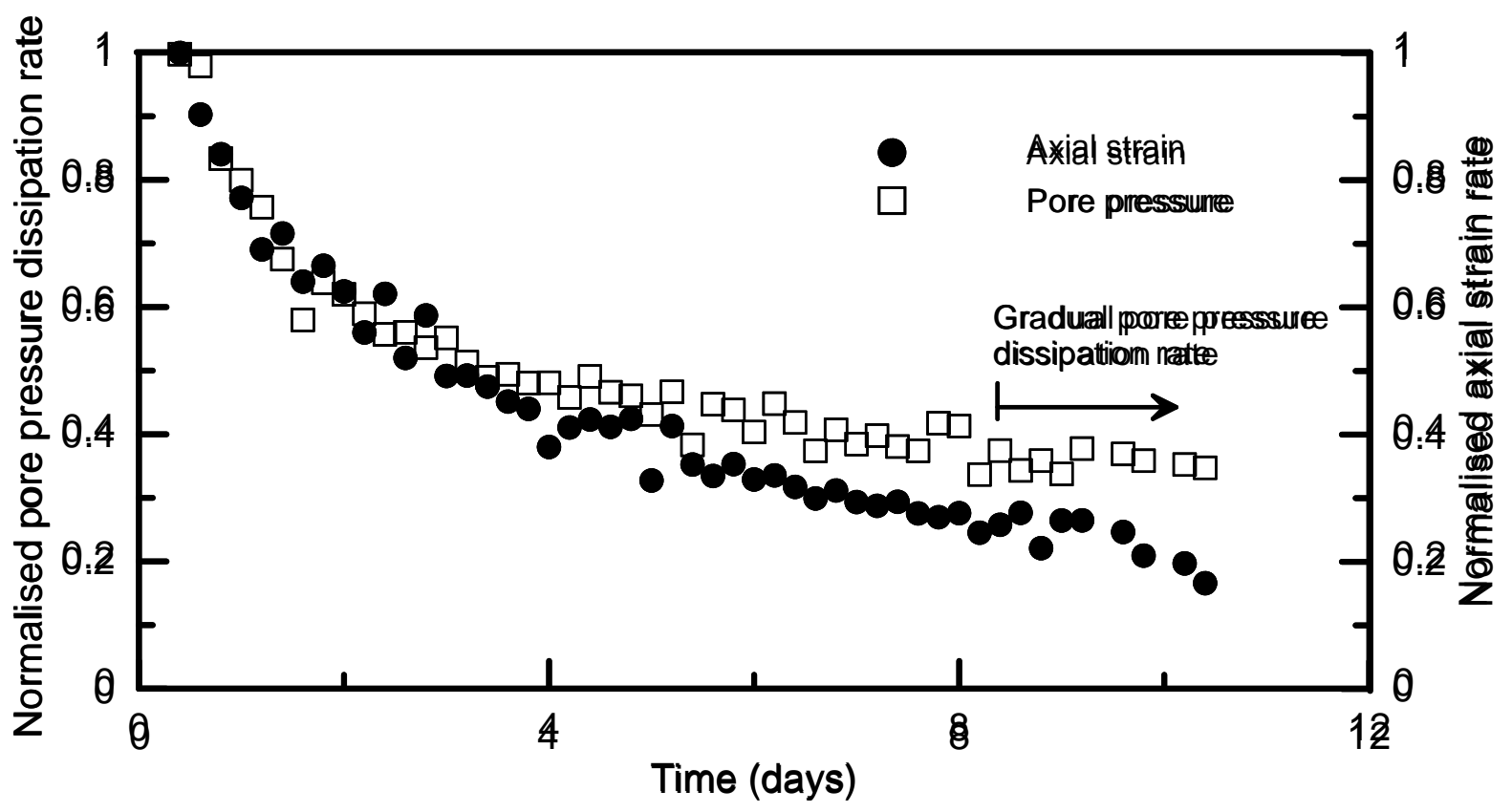

Fig .5 Normalised pore pressure dissipation rate and Normalised axial strain rate 


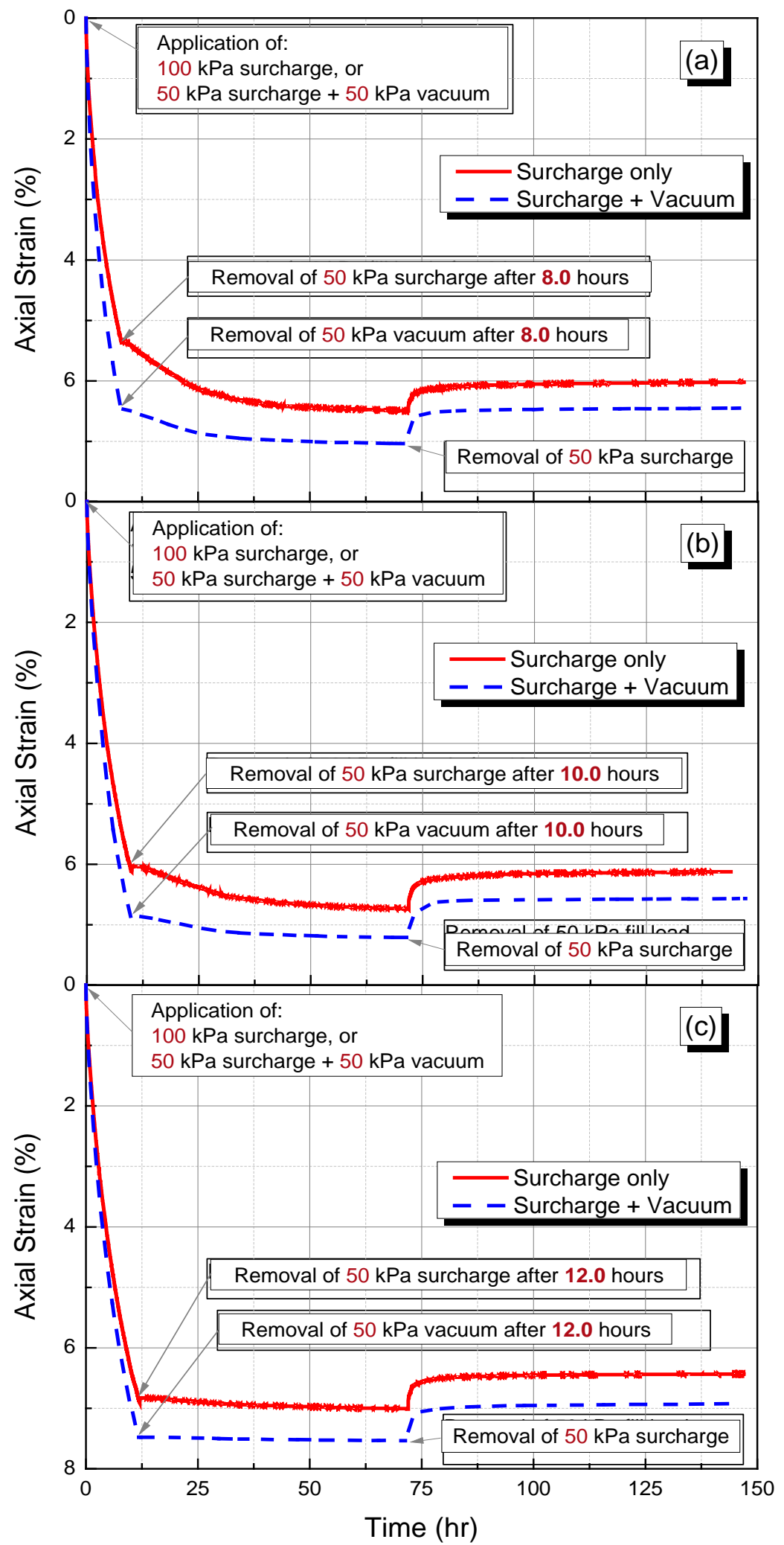

Figure 6: Axial strain for: (a) removal of fill/vacuum at 8.0 hours,(b) removal of fill/vacuum at10.0 hours, (c) removal of fill/vacuum at 12.0 hours, 


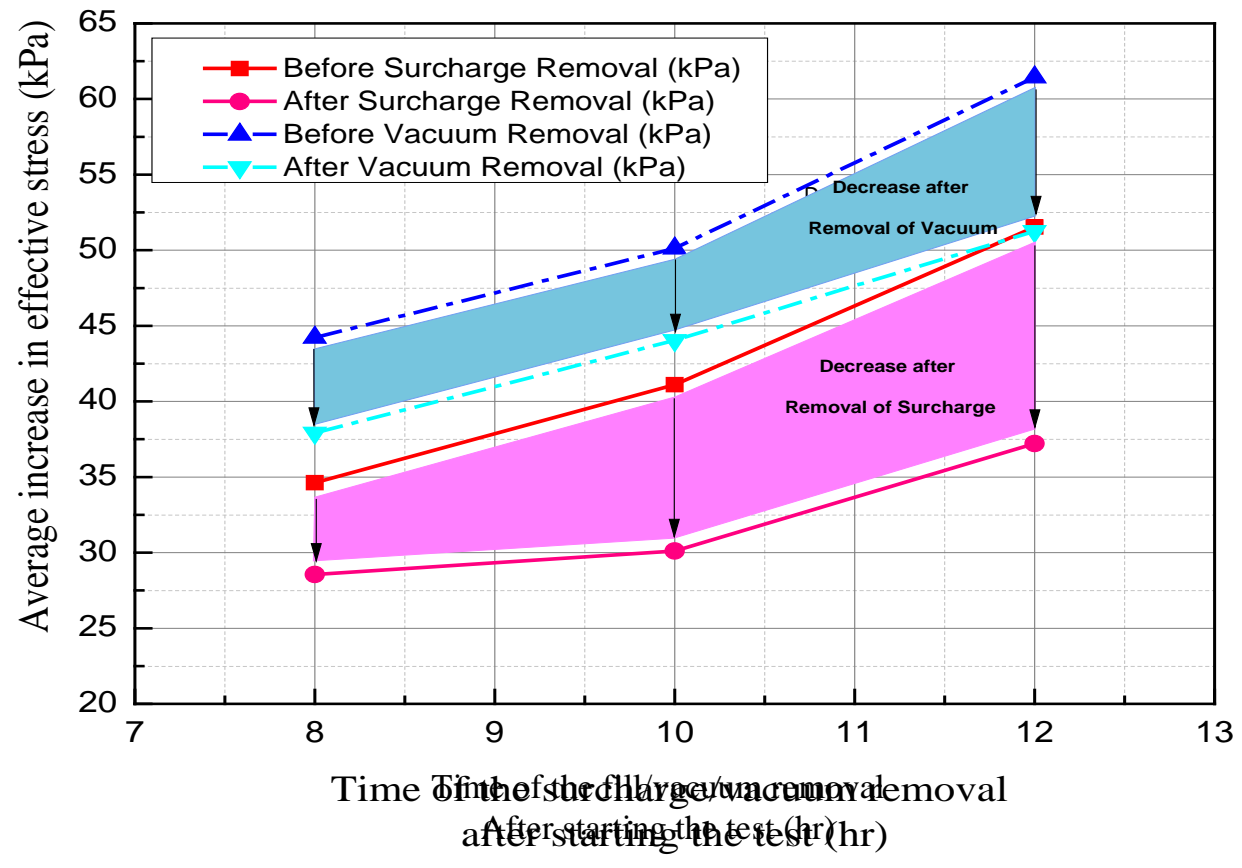

Figure 7: Decrease of the average effective stress with the time of the fill/vacuum removal. 


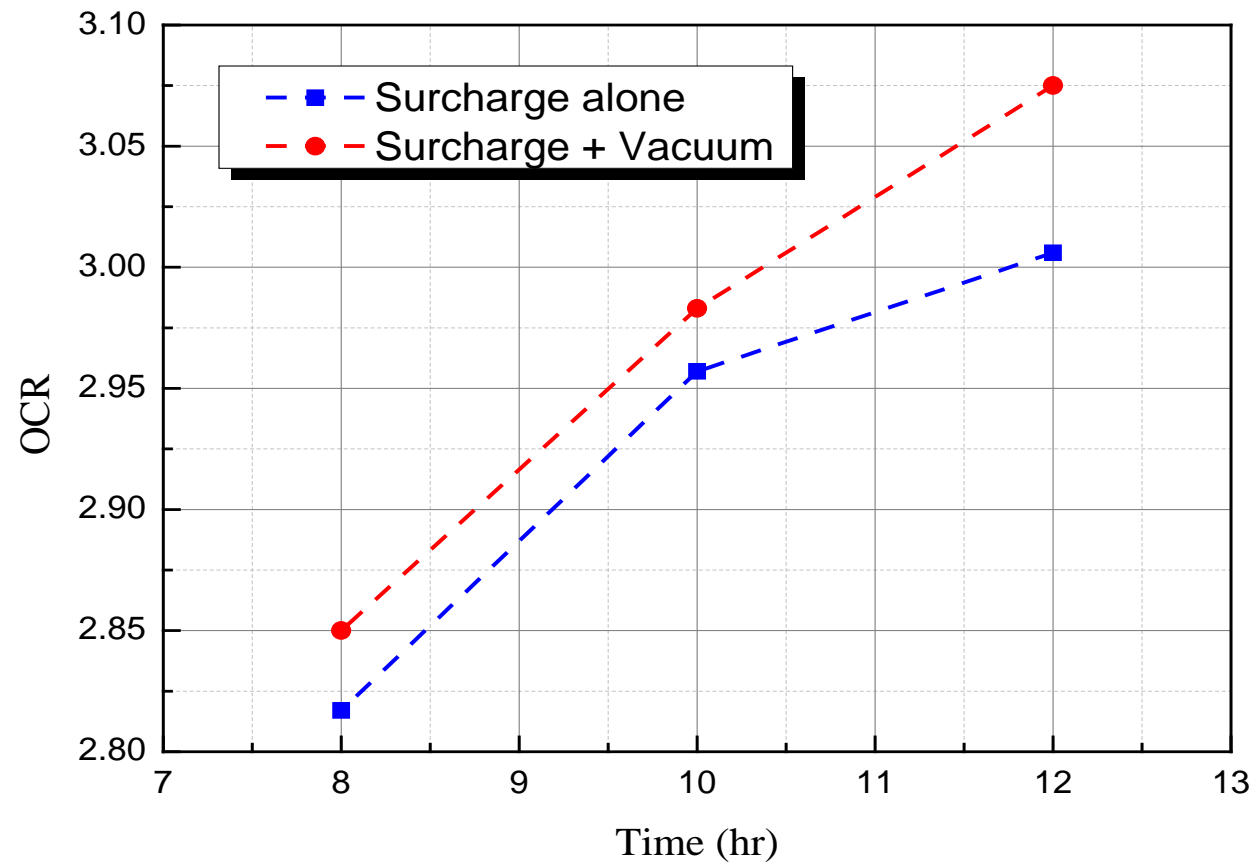

Figure 8: Average overconsolidation ratio computed using average values of pore water pressure with removal time of fill/vacuum 